\title{
COMPARATIVE CHEMICAL CHARACTERISATION OF SOILS AT CYPRIPEDIUM CALCEOLUS SITES IN LATVIA
}

\author{
Dace Kḷvinaa ${ }^{1, \#}$ and Anita Osvalde ${ }^{2}$ \\ ${ }^{1}$ National Botanic Garden of Latvia, Miera iela 1, Salapils, LV-2169, LATVIA; \\ dace.klavina@nbd.gov.lv \\ ${ }^{2}$ Institute of Biology of the University of Latvia, Miera iela 3, Salapils, LV-2169, LATVIA; \\ augi@lu.Iv \\ \# Corresponding author
}

Communicated by Vieturs Melecis

The main aim of the study was to evaluate the soil chemical characteristics of Cypripedium calceolus sites in Latvia for understanding of the species ecology, and its conservation problems and possibilities. Soil for 27 C. calceolus sites in Latvia was analysed during 2007-2015. The concentration of plant available essential nutrients ( $N, P, K, C a, M g, S, F e, M n, Z n, C u, M o, B$ ), soil $\mathrm{pH}$, electrical conductivity and concentration of organic matter were determined. Nutrient concentration of $\mathrm{C}$. calceolus leaf samples from six sites were determined. The results demonstrated high heterogeneity in soil chemical composition with high variation for $\mathrm{Ca}, \mathrm{Mg}$, and $\mathrm{Mn}$. The results suggest some relationship between soil organic matter content and size of the orchid population. Soil $\mathrm{pH}$ and $\mathrm{Ca}$ concentration did not affect the size and vitality of $\mathrm{C}$. calceolus populations in Latvia. There was no significant correlation between nutrient concentration in soil and C. calceolus leaves suggesting strong impact of other soil-related factors in determining the availability of nutrients. In general, the levels of $\mathrm{N}, \mathrm{P}, \mathrm{K}, \mathrm{Ca}, \mathrm{Mg}, \mathrm{Fe}, \mathrm{Mn}$, and $\mathrm{Zn}$ concentrations in $\mathrm{C}$. calceolus leaves were adequate or slightly decreased for successful orchid growth. The study showed deficiency of $\mathrm{S}, \mathrm{Cu}$, and B in the vast majority of leaf samples. C. calceolus sites in Latvia occur mainly on organic soils or mineral soils with high content of organic matter. There was a weak positive correlation ( $r=0.21)$ observed only between total number of ramets of $\mathrm{C}$. calceolus in site and Ca concentration in the soil, suggesting that soil properties are not a main factor affecting species abundance in the site.

Key words: Cypripedium calceolus, mineral nutrients, $\mathrm{pH}$, organic matter, habitats.

\section{INTRODUCTION}

Cypripedium calceolus is a long-lived rhizomatous species with specific mycotrophic adaptation related to a functional type of rare plants with a narrow ecological niche (Mihalchuk, 2011). The initial development of young C. calceolus plants is very slow and the first flowering is delayed for at least 10 years. Adult plants survival is high. Species immigration and colonisation success is low and it subjected to strong interspecific competition (Devillers-Treschuren, 1999). C. calceolus inhabits temperate and boreal zones of Europe, Siberia and Central and East Asia (Cribb, 1997) and in most of its range it is a rare species both in number of sites and number of individuals (Devillers-Treschuren, 1999). It is one of the 14 vascular plant species specific for natural forest habitats in Latvia (Auniņš, 2013).

The species is protected in the majority of European countries (in Latvia since 1977), and included in the protected plant lists of Bern and Washington conventions as well as in Annex II of the European Council Habitats Directive 92/43/EEC. It is included in Regulations No. 396 of the Cabinet of Minister of Latvia on protected species and in the second (vulnerable) threat category in the Red Data Book of Latvia (Andrušaitis, 2003). Strict species protection in many countries was enacted after its decline throughout almost its entire distribution range (Devillers-Treschuren, 1999).

Formerly it was known from 62 localities in Latvia (Cepurite, 2005). In chorological material of the Latvian flora (Ābele et al., 1978), 42 sites for this species were listed, in Red Data Book - 53 (Andrušaitis, 2003), but C. calceolus is now present only in 27 sites, which were confirmed in the present study. The reduction of suitable habitats for this narrowly specialised species is a major threat (DevillersTreschuren, 1999). The main factors limiting C. calceolus establishment and survival in particular microhabitats are 
not known. Preliminary results of recent research on $C$. calceolus in Latvia were described by Klavina et al. (2014), but no data referring all sites of this species in Latvia have been presented previously. One of the important abiotic factors for establishment and growth of a species is suitable soil conditions. Only few publications provide soil characteristics for C. calceolus sites (Arditti, 1992; Kull, 1999; 2003; Reshetjuk, 2011). Therefore, more detailed studies on the role of soil chemical composition, especially on significance of $\mathrm{Ca}$ and $\mathrm{pH}$ on distribution of this calciole, are necessary. To gain better understanding of the ecology of the species and conservation issues and possibilities we started with analysis and characterisation of soil chemical composition of $C$. calceolus sites in Latvia. Soil studies are also important for comparing growth conditions in inhabited sites and in prospective sites (Ramsay, 1998) for re-introduction.

The aim of the study was to evaluate the soil chemical characteristics of $C$. calceolus sites in Latvia for better understanding of the ecology of the species and conservation issues and possibilities.

\section{MATERIAL AND METHODS}

Twenty seven sites in different types of habitats with $C$. calceolus, located throughout Latvia, were investigated during 2007-2015 (Fig. 1). Data on the species distribution were extracted from the data system OZOLS (Anonymous, 2012). A distribution map was prepared using a $10 \times 10 \mathrm{~km}$ grid (Laiviņš and Krampis, 2004). The sites listed in Tables were arranged and numbered from west to east of Latvia, but in Figures the sites were marked with abbreviations of the site name.

The total number of ramets and generative ramets were recorded in each site (unpublished data). In the present paper these data were used only partly for characterisation of the impact of soil organic matter and $\mathrm{Ca}$ content on the C. calceolus population in Latvia.

Sampling. C. calceolus soil and plant leaf samples were collected for laboratory analysis. The soil samples were taken from the root zone near C. calceolus plants to $20 \mathrm{~cm}$ depth. For each sample at least five sub-samples were collected and mixed into a single sample $(0.5-1 \mathrm{~L})$. During the study period, soil samples were taken at least two times at each location. A more detailed investigation was conducted in Kemeri, Dunduri, Katleši, Lielie Kangari, Numerne, Silzemnieki, Slītere, and Sloka (the largest and/or nearest populations). Completely developed leaves from about 10-15 plants were taken for each leaf sample. Leaf samples from six sites were taken twice, in 2012 and 2013.

Laboratory analysis. Collected soil samples were air-dried and sieved through a 2-mm sieve. To determine available concentrations of 12 essential nutrients (N, P, K, Ca, Mg, S, $\mathrm{Fe}, \mathrm{Mn}, \mathrm{Zn}, \mathrm{Cu}, \mathrm{Mo}$, and $\mathrm{B}$ ) the soil samples were extracted with $1 \mathrm{M} \mathrm{HCl}$ solution (soil/extractant volume ratio 1:5), extraction time $1 \mathrm{~h}$. Leaf samples of $C$. calceolus were dried at $+60{ }^{\circ} \mathrm{C}$ temperature, ground, dry-ashed in concentrated $\mathrm{HNO}_{3}$ vapour and re-dissolved in $\mathrm{HCl}$ solution $(\mathrm{HCl}-$ distilled water mixture 3:100) (Rinkis et al., 1987).

The concentration of organic matter in soils was determined according to Tjurin (Rinkis et al., 1987). Based on the concentration of organic matter, the soils were classified as mineral soils (0-10\% organic matter), soils with high concentration of organic matter (11-60\% organic matter), and organic soils (61-100\% organic matter). In the Stikli site, organic matter in the soil was not detected.

The levels of $\mathrm{Ca}, \mathrm{Mg}, \mathrm{Fe}, \mathrm{Cu}, \mathrm{Zn}$, and $\mathrm{Mn}$ were estimated by an atomic absorption spectrophotometer Perkin Elmer

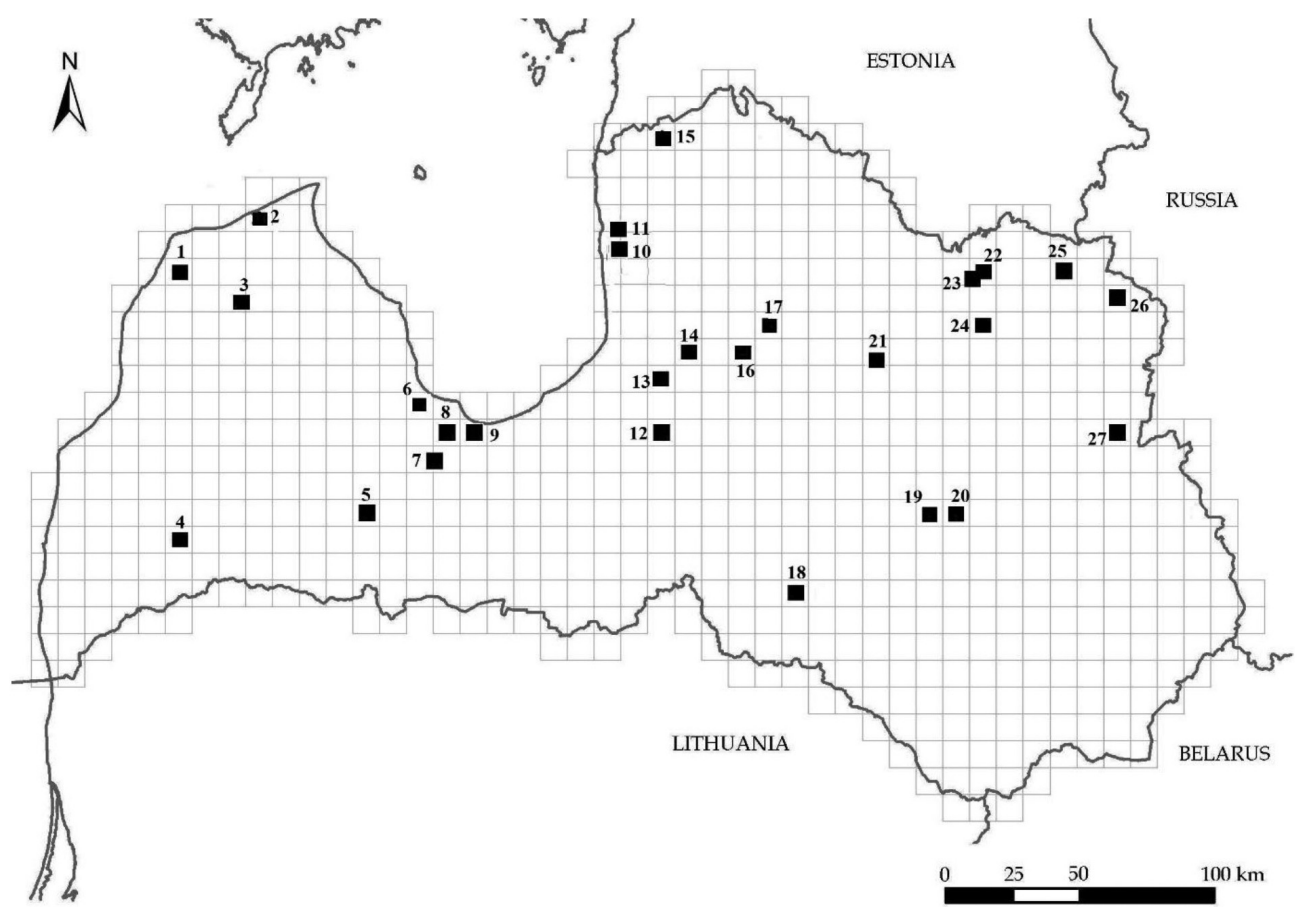

Fig. 1. Location of sites of Cypripedium calceolus in Latvia. 
AAnalyst 700 (Page et al., 1982; Anonymous, 2000), the levels of N, P, Mo, B by colorimetry, S by turbidimetry (spectrophotometer JENWAY 6300), and K with a flame photometer (Jenway PFP7) (Rinkis et al., 1987).

Soil $\mathrm{pH}$ was measured in a $1 \mathrm{M} \mathrm{KCl}$ suspension and electrical conductivity (EC) using distilled water extract (Rinkis et al., 1987).

The statistical analysis of the data was conducted using MS Excel 2013. Means and standard error were calculated. Heterogeneity of nutrient concentrations was characterised by the coefficient of variation $(\mathrm{CV})$. One-way analysis of variance (ANOVA) was used to compare all soil parameters within the site, and among sites and soil groups (organic and mineral soils) (Fowler et al., 1998). Pearson correlation coefficients were calculated to evaluate correlation between soil parameter and abundance of generative ramets of $C$. calceolus. To characterise $C$. calceolus abundance, three parameters were tested: total number of ramets, number of generative ramets and relative number of generative ramets (proportion of generative ramets among all ramets observed).

\section{RESULTS}

In general, a vast range of nutrient concentrations were found in different $C$. calceolus sites in Latvia (Tables 1,2). Although soil samples were collected at different times (2007-2015), ANOVA analysis showed that the values of parameters within sites was homogenous. One-way analysis of variance (ANOVA) showed significant difference $(p<$ 0.05 ) in concentration of all analysed chemical elements in soils between sites, excepting for potassium.

Among macronutrients, the highest coefficient of variation was found for $\mathrm{Mn}(77 \%)$ and the lowest for $\mathrm{N}(37 \%)$. Among micronutrients, the highest variability of concentration was found for Mo (197\%) and Mn (77\%), and lowest for $\mathrm{Cu}(38 \%)$. In general, a low range was characteristic for electrical conductivity (EC), to a large extent reflecting low variability of concentrations of mobile nutrients (mainly $\mathrm{N}$ and $\mathrm{K}$ ) in soils at $C$. calceolus sites.

The $\mathrm{pH}_{\mathrm{KCl}}$ values in soils (Fig. 2) from C. calceolus sites ranged in a comparatively wide amplitude: from moderately acidic $\left(\mathrm{pH}_{\mathrm{KCl}}\right.$ 5.19) to slightly alkaline $\left(\mathrm{pH}_{\mathrm{KCl}}\right.$ 7.39).

Table 1

CONCENTRATION (MEAN \pm SE, MG/L, 1M HCL EXTRACTION) OF MACRONUTRIENTS IN AIR-DRY SOILS FROM DIFFERENT CYPRIPEDIUM CALCEOLUS SITES IN LATVIA

\begin{tabular}{|c|c|c|c|c|c|c|c|c|c|}
\hline No. & Locality & Abbreviations & $\mathrm{N}$ & $\mathrm{P}$ & K & $\mathrm{Ca}$ & $\mathrm{Mg}$ & $\mathrm{S}$ & $\mathrm{Mg} / \mathrm{K}$ \\
\hline 1 & Klāṇi & Klā & $75.0 \pm 25.0$ & $50.5 \pm 1.5$ & $62.0 \pm 7.0$ & $11150 \pm 4850$ & $223 \pm 78$ & $19.0 \pm 10.0$ & 3.6 \\
\hline 2 & Slītere & Slīt & $87.7 \pm 16.5$ & $48 \pm 2.6$ & $97.7 \pm 16.2$ & $11867 \pm 573$ & $1517 \pm 99$ & $34.0 \pm 8.4$ & 15.5 \\
\hline 4 & Gravinas & Grav & $44.5 \pm 9.5$ & $14.5 \pm 6.5$ & $58.0 \pm 8.0$ & $75750 \pm 250$ & $715 \pm 65$ & $25.5 \pm 9.5$ & 12.3 \\
\hline 5 & Svēte & Svēt & $37.0 \pm 5.5$ & $109 \pm 8.8$ & $185.0 \pm 15.0$ & $4950 \pm 190$ & $800 \pm 45$ & $12.0 \pm 1.5$ & 6.5 \\
\hline 6 & Dubļukrogs & Dub & $152.5 \pm 22.5$ & $93.0 \pm 0.0$ & $78.0 \pm 2.0$ & $7725 \pm 25$ & $508 \pm 83$ & $34.0 \pm 1.0$ & 6.5 \\
\hline 7 & Dunduri & Dun & $49.8 \pm 4.6$ & $17.4 \pm 7.8$ & $48.6 \pm 5.1$ & $8218 \pm 554$ & $133 \pm 25$ & $93.2 \pm 11.2$ & 2.7 \\
\hline 8 & Ķemeri & Kem & $50.3 \pm 6.9$ & $26.0 \pm 5.5$ & $98.5 \pm 20.3$ & $40054 \pm 3283$ & $26705 \pm 2207$ & $33.6 \pm 4.6$ & 271.1 \\
\hline 9 & Sloka & Slo & $55.4 \pm 9.7$ & $50.9 \pm 2.7$ & $84.6 \pm 4.8$ & $6432 \pm 374$ & $589 \pm 229$ & $56.6 \pm 11.9$ & 7.0 \\
\hline 10 & Tūja & Tūja & $104.0 \pm 15.5$ & $113.0 \pm 15.0$ & $64.0 \pm 5.8$ & $8100 \pm 525$ & $570 \pm 28$ & $31.0 \pm 5.2$ & 8.9 \\
\hline 11 & Vitrupe & Vitr & $96.0 \pm 10.0$ & $87.0 \pm 6.5$ & $59.0 \pm 7.0$ & $7200 \pm 380$ & $585 \pm 60$ & $29.0 \pm 1.8$ & 9.9 \\
\hline 12 & Lielie Kangari & LKan & $64.7 \pm 11.3$ & $128.3 \pm 21.7$ & $49.0 \pm 8.0$ & $11750 \pm 144$ & $3990 \pm 311$ & $18.3 \pm 4.1$ & 81.4 \\
\hline 14 & Silzemnieki & Silz & $76.6 \pm 8.1$ & $126.6 \pm 6.7$ & $69.2 \pm 6.8$ & $6471 \pm 311$ & $636 \pm 31$ & $20.2 \pm 2.4$ & 9.2 \\
\hline 15 & Ziemeḷu purvi & Ziem & $98.0 \pm 8.5$ & $61.0 \pm 10.0$ & $37.0 \pm 4.0$ & $7000 \pm 380$ & $690 \pm 25$ & $24.0 \pm 2.5$ & 18.7 \\
\hline 16 & Pērḷupe & Pērḷ & $55.0 \pm 5.8$ & $42.0 \pm 5.5$ & $51.0 \pm 7.5$ & $79500 \pm 650$ & $635 \pm 58$ & $238.0 \pm 25.0$ & 12.5 \\
\hline 17 & Kazu grava & $\mathrm{Kaz}$ & $80.0 \pm 5.6$ & $68.0 \pm 7.5$ & $195.0 \pm 28.0$ & $14850 \pm 550$ & $8950 \pm 350$ & $17.0 \pm 1.5$ & 45.9 \\
\hline 18 & Slapjo salu purvs & Slsp & $88.0 \pm 10.0$ & $28.0 \pm 3.5$ & $90.0 \pm 9,5$ & $4320 \pm 225$ & $1080 \pm 35$ & $29.0 \pm 2.5$ & 12.0 \\
\hline 19 & Isliena & Isl & $102.0 \pm 9.4$ & $50.0 \pm 4.8$ & $73.0 \pm 5.5$ & $5200 \pm 450$ & $790 \pm 65$ & $9.0 \pm 0.5$ & 10.8 \\
\hline 20 & Murmastiene & Mur & $51.0 \pm 7.2$ & $97.0 \pm 10.0$ & $145.0 \pm 11.8$ & $4245 \pm 328$ & $565 \pm 25$ & $9.0 \pm 1.0$ & 3.9 \\
\hline 21 & Druviena & Druv & $32.0 \pm 3.5$ & $94.0 \pm 8.5$ & $195.0 \pm 19.5$ & $16000 \pm 625$ & $4100 \pm 115$ & $13.0 \pm 3.2$ & 21.0 \\
\hline 22 & Zāgadi & Zāg & $70.5 \pm 1.5$ & $74.5 \pm 18.5$ & $80.0 \pm 1.0$ & $7800 \pm 350$ & $840 \pm 80$ & $17.0 \pm 4.0$ & 10.5 \\
\hline 23 & Zeltiņi & Zelt & $99.0 \pm 11.0$ & $70.0 \pm 11.0$ & $62.5 \pm 3.5$ & $7650 \pm 550$ & $568 \pm 3$ & $31.5 \pm 3.5$ & 9.1 \\
\hline 24 & Gulbene & Gulb & $80.0 \pm 0.0$ & $67.5 \pm 5.5$ & $74.5 \pm 2.5$ & $8475 \pm 225$ & $753 \pm 13$ & $16.0 \pm 2.0$ & 10.1 \\
\hline 25 & Beja & Beja & $62.0 \pm 4.0$ & $46.5 \pm 27.0$ & $76.5 \pm 29.0$ & $12981 \pm 5037$ & $850 \pm 200$ & $18.0 \pm 12.0$ & 11.1 \\
\hline 26 & Katleši & Katl & $56.8 \pm 6.8$ & $50.3 \pm 5.7$ & $54.3 \pm 5.7$ & $5716 \pm 725$ & $635 \pm 77$ & $12.8 \pm 1.4$ & 11.7 \\
\hline 27 & $\mathrm{CV}^{*}, \%$ & & 37.0 & 51.4 & 51.7 & 137.1 & 234.7 & 136.6 & \\
\hline
\end{tabular}

* Coefficient of variation 
Table 2

MICRONUTRIENT CONCENTRATION (MEAN \pm SE, MG/L, 1M HCL EXTRACTION) IN AIR-DRY SOILS AND ELECTRICAL CONDUCTIVITY (WATER EXTRACT) FROM DIFFERENT CYPRIPEDIUM CALCEOLUS SITES IN LATVIA

\begin{tabular}{|c|c|c|c|c|c|c|c|c|c|}
\hline & Locality & $\mathrm{Fe}$ & $\mathrm{Mn}$ & $\mathrm{Zn}$ & $\mathrm{Cu}$ & Mo & $\mathrm{B}$ & $\mathrm{EC} \mathrm{mS/cm}$ & $\mathrm{Fe} / \mathrm{Mn}$ \\
\hline 1 & Klāṇi & $340 \pm 130$ & $62 \pm 8$ & $6.8 \pm 0.3$ & $1.9 \pm 0.5$ & $0.04 \pm 0.01$ & $1.1 \pm 0.2$ & $0.56 \pm 0.16$ & 5.5 \\
\hline 2 & Slītere & $1223 \pm 278$ & $130 \pm 13$ & $11.8 \pm 2.0$ & $1.0 \pm 0.1$ & $0.03 \pm 0.00$ & $1.8 \pm 0.2$ & $0.90 \pm 0.12$ & 9.4 \\
\hline 4 & Graviņas & $29 \pm 17$ & $108 \pm 13$ & $2.4 \pm 0.7$ & $0.8 \pm 0.3$ & $0.11 \pm 0.09$ & $0.9 \pm 0.6$ & $0.92 \pm 0.03$ & 0.3 \\
\hline 5 & Svēte & $630 \pm 55$ & $340 \pm 35$ & $10.5 \pm 0.9$ & $1.8 \pm 0.2$ & $0.02 \pm 0.00$ & $0.9 \pm 0.2$ & $0.54 \pm 0.04$ & 1.9 \\
\hline 6 & Dubḷukrogs & $383 \pm 23$ & $283 \pm 13$ & $6.0 \pm 0.0$ & $1.1 \pm 0.05$ & $0.02 \pm 0,00$ & $1.5 \pm 0.1$ & $0.62 \pm 0.10$ & 1.4 \\
\hline 7 & Dunduri & $112 \pm 12$ & $18 \pm 7$ & $3.9 \pm 0.9$ & $0.5 \pm 0.1$ & $0.03 \pm 0.00$ & $3.8 \pm 0.7$ & $1.38 \pm 0.17$ & 6.1 \\
\hline 8 & Ķemeri & $609 \pm 113$ & $229 \pm 13$ & $8.3 \pm 1.3$ & $1.4 \pm 0.4$ & $0.02 \pm 0.00$ & $0.4 \pm 0.1$ & $0.78 \pm 0.11$ & 2.7 \\
\hline 9 & Sloka & $374 \pm 43$ & $22 \pm 2$ & $3.1 \pm 0.3$ & $1.7 \pm 0.1$ & $0.03 \pm 0.01$ & $1.5 \pm 0.2$ & $0.90 \pm 0.08$ & 17.3 \\
\hline 10 & Tūja & $895 \pm 95$ & $355 \pm 30$ & $6.5 \pm 0.4$ & $1.2 \pm 0.2$ & $0.02 \pm 0.00$ & $2.1 \pm 0.2$ & $0.61 \pm 0.03$ & 2.5 \\
\hline 11 & Vitrupe & $1680 \pm 120$ & $680 \pm 58$ & $8.5 \pm 0.6$ & $1.8 \pm 0.1$ & $0.07 \pm 0.01$ & $1.4 \pm 0.2$ & $0.53 \pm 0.03$ & 2.5 \\
\hline 12 & Lielie Kangari & $837 \pm 149$ & $227 \pm 27$ & $15.2 \pm 5.4$ & $1.1 \pm 0.2$ & $0.03 \pm 0.00$ & $0.1 \pm 0.0$ & $0.52 \pm 0.05$ & 3.6 \\
\hline 14 & Silzemnieki & $316 \pm 42$ & $192 \pm 16$ & $6.3 \pm 0.8$ & $1.4 \pm 0.1$ & $0.03 \pm 0.00$ & $1.3 \pm 0.3$ & $0.63 \pm 0.07$ & 1.7 \\
\hline 15 & Ziemeḷu purvi & $760 \pm 100$ & $230 \pm 20$ & $1.5 \pm 0.1$ & $1.5 \pm 0.2$ & $0.04 \pm 0.00$ & $1.0 \pm 0.2$ & $0.62 \pm 0.04$ & 3.3 \\
\hline 16 & Pērḷupe & $17 \pm 5$ & $60 \pm 6$ & $3.6 \pm 0.2$ & $0.9 \pm 0.1$ & $0.02 \pm 0.00$ & $1.8 \pm 0.3$ & $0.76 \pm 0.05$ & 0.3 \\
\hline 17 & Kazu grava & $400 \pm 45$ & $430 \pm 35$ & $3.5 \pm 0.4$ & $1.6 \pm 0.2$ & $0.03 \pm 0.00$ & $0.7 \pm 0.2$ & $0.53 \pm 0.02$ & 0.9 \\
\hline 18 & Slapjo salu purvs & $260 \pm 30$ & $170 \pm 15$ & $1.9 \pm 0.3$ & $0.8 \pm 0.1$ & $0.07 \pm 0.01$ & $1.1 \pm 0.1$ & $0.78 \pm 0.06$ & 1.5 \\
\hline 19 & Isliena & $1605 \pm 150$ & $185 \pm 18$ & $3.5 \pm 0.3$ & $1.0 \pm 0.2$ & $0.02 \pm 0.00$ & $1.5 \pm 0.3$ & $0.66 \pm 0.05$ & 8.7 \\
\hline 20 & Murmastiene & $1340 \pm 150$ & $105 \pm 9$ & $4.9 \pm 0.5$ & $3.0 \pm 0.2$ & $0.04 \pm 0.00$ & $0.8 \pm 0.1$ & $0.41 \pm 0.02$ & 12.8 \\
\hline 21 & Druviena & $695 \pm 80$ & $65 \pm 5.5$ & $3.2 \pm 0.4$ & $1.5 \pm 0.1$ & $0.03 \pm 0.00$ & $0.1 \pm 0.0$ & $0.52 \pm 0.05$ & 10.7 \\
\hline 22 & Zāgadi & $553 \pm 243$ & $283 \pm 63$ & $5.0 \pm 0.0$ & $1.6 \pm 0.4$ & $0.04 \pm 0.00$ & $1.9 \pm 0.5$ & $0.66 \pm 0.02$ & 2.0 \\
\hline 23 & Zeltiņi & $1305 \pm 220$ & $332 \pm 138$ & $3.5 \pm 0.5$ & $1.5 \pm 0.1$ & $0.06 \pm 0.00$ & $1.3 \pm 0.1$ & $0.62 \pm 0.04$ & 3.9 \\
\hline 24 & Gulbene & $1298 \pm 138$ & $653 \pm 8$ & $2.3 \pm 0.8$ & $1.6 \pm 0.2$ & $0.06 \pm 0.03$ & $2.0 \pm 0.1$ & $0.73 \pm 0.07$ & 2.0 \\
\hline 25 & Beja & $525 \pm 100$ & $145 \pm 85$ & $12.3 \pm 3.5$ & $1.6 \pm 0.4$ & $0.07 \pm 0.05$ & $2.0 \pm 0.7$ & $0.67 \pm 0.22$ & 3.7 \\
\hline 27 & $\mathrm{CV}^{*}, \%$ & 66.5 & 75.7 & 61.4 & 37.9 & 52.6 & 56.6 & 29.8 & \\
\hline
\end{tabular}

* Coefficient of variation

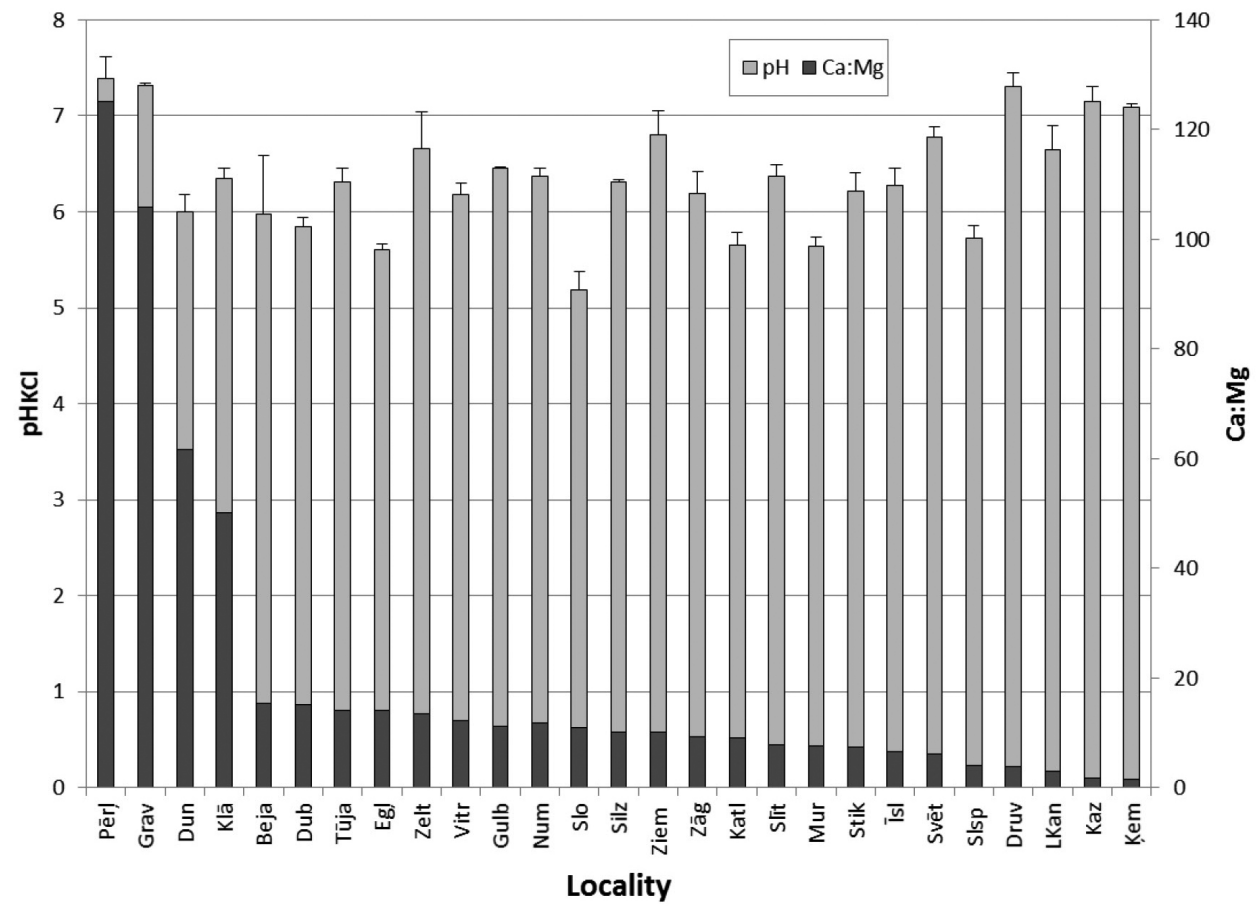

Fig. 2. $\mathrm{pH}_{\mathrm{KCl}}$ and $\mathrm{Ca}: \mathrm{Mg}$ ratio in soils from Cypripedium calceolus sites in Latvia. 


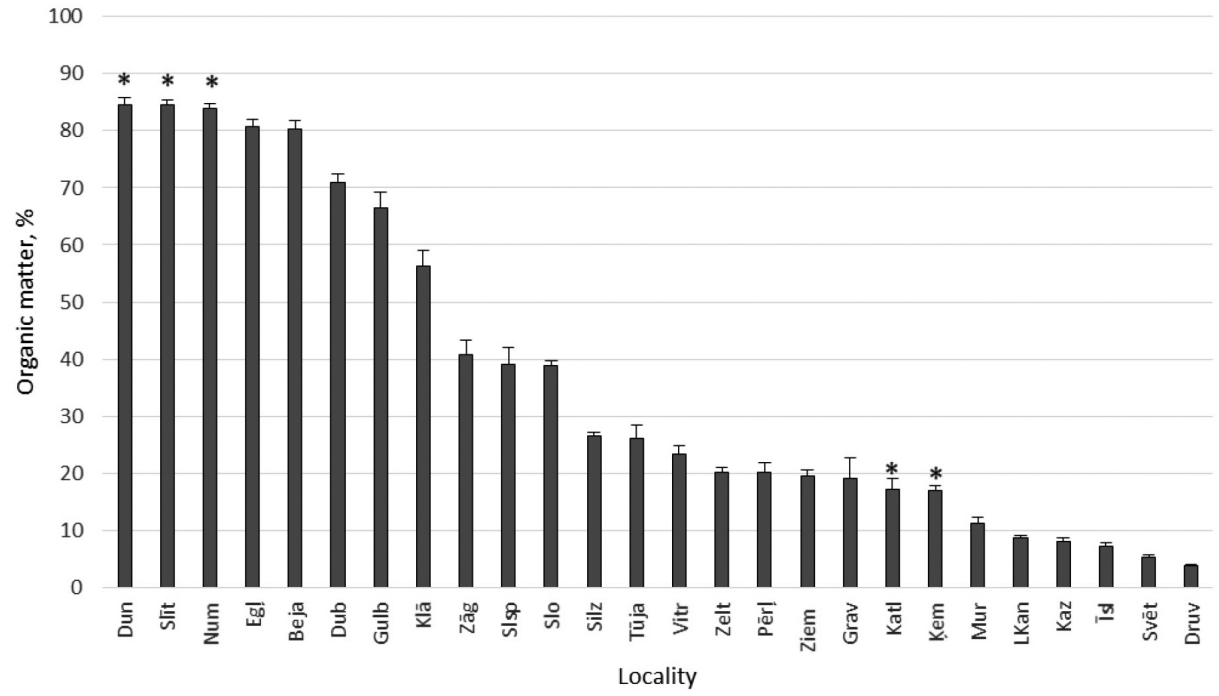

Fig. 3. Organic matter content in soils from Cypripedium calceolus sites in Latvia.

* the largest populations of Cypripedium calceolus: Kemeri - 1400 ramets, Katleši 1135 ramets, Dunduri - 511 ramets, Numerne - 304 ramets, Slïtere - 200 ramets.

Among macronutrients, there were low mean concentrations of $\mathrm{N}$ at about half of the study sites. On the other hand, soils of sites Dublikrogs, Tūja, and Zeltini were rich in nitrogen (N 100-153 mg/L), compared to the other study sites. High organic matter content was also characteristic for those sites (Fig. 3). A mean concentration of P higher than $120 \mathrm{mg} / \mathrm{L}$ was found only at two study sites (Silzemnieki and Lielie Kangari), while at about half of the sites the level of $\mathrm{P}$ did not exceed $50 \mathrm{mg} / \mathrm{L}$. A high $\mathrm{K}$ concentration occurred at Svēte, Kazu grava, Murmastiene, and Druviena) and S only in few $C$. calceolus sites (Dunduri and Sloka) located mainly on mineral soils. An extremely high S concentration was observed at Pērlupe - $238 \mathrm{mg} / \mathrm{L}$. Along with variable $\mathrm{pH}_{\mathrm{KCl}}$ values, the concentrations of $\mathrm{Ca}$ and $\mathrm{Mg}$ varied by 19 and 200 times, respectively, when comparing minimum and maximum values.

Although high heterogenity was found for all micronutrients, the highest differences were found for $\mathrm{Fe}$ and $\mathrm{Mn}$, which were mainly due to specific soil characteristics in $C$. calceolus habitats (mineral or organic soil, degree of organic matter decomposition).

Electrical conductivity, which characterises the concentration of water soluble ions in soil extract, showed moderate availability of these nutrients in most sites (Table 2), except in soil from Dunduri (EC $1.38 \mathrm{mS} / \mathrm{cm}$ ). The raised electrical conductivity at this site was due to high $\mathrm{S}$ content caused by gypsum deposits in this site (high $\mathrm{Ca}$ and $\mathrm{S}$ and low $\mathrm{Mg}$ content, Table 1).

Analysis of nutrient ratios, which is an important factor in plant mineral nutrition, showed that in soil samples from $C$. calceolus sites the concentration of $\mathrm{Mg}$ was about 3-271 times higher than the $\mathrm{K}$ concentrations (Table 1). The high $\mathrm{Mg}$ concentrations occurred in soils with soil reaction close to neutral. The Ca: $\mathrm{Mg}$ ratio in soils of the investigated sites varied from 1.5 (Kemeri - dolomite) up to 125 (Pērlupe limestone) (Fig. 2) indicating the presence of diverse parent soil in different sites.

Some extremely low Fe:Mn ratio (Table 2) were found for slope forests at Gravinas, Pērlupe, Kazu grava, where the concentration of $\mathrm{Mn}$ was higher than $\mathrm{Fe}$.
The soils of the studied C. calceolus sites in Latvia mainly (14 sites) had high concentration of organic matter $(11-56 \%)$. Seven sites were found on organic soils (organic matter content $66-85 \%$ ) and five sites on typical mineral soils with organic content less than $10 \%$ (Fig. 3). Potassium concentration, electrical conductivity and organic content significantly differed among these three soil groups $(p<$ $0.05)$. The results showed some relationship between soil organic matter content and size of orchid population. The largest C. calceolus populations in Latvia Kemeri (1400 ramets) and Katleši (1135 ramets) occurred on soils with high concentration of organic matter (organic matter content 17\%), and three other large populations: Dunduri (511 ramets), Slitere (200 ramets), Numerne (304 ramets) on organic soils (organic matter content $84-85 \%$ ) (Figure 3).

A negative correlation $(\mathrm{r}=-0.44 ; p<0.05)$ was observed between the relative number of generative ramets of $C$. calceolus and $\mathrm{Ca}$ concentration in the soil (Fig. 4) and a weak positive correlation $(\mathrm{r}=0.21)$ - between total number of ramets of $C$. calceolus in a site and Ca concentration in the soil.

To get more detailed information about nutrient status of $C$. calceolus, concentration of 12 biogenous elements were determined also in orchid leaf samples from selected sites in 2010-2013 (Table 3). In general, heterogenity of leaf nutrient concentrations was lower than for the concentrations in soil. Among macronutrients, the minimum and maximum concentration of $\mathrm{K}$ in leaves differed by 2.6 times; among micronutrients the largest difference between maximum and minimum concentrations was found for $\mathrm{Cu}$ (4.0 times) and Mn (2.4 times).

Some incoherence was found between nutrient concentrations in soils and leaves at C. calceolus sites (Tables 1-3). For example, $\mathrm{K}$ concentration in plants at the Katleši site where $\mathrm{K}$ content in soils was low $(54 \mathrm{mg} / \mathrm{L})$ was the same as that in plants from Kemeri, where the $\mathrm{K}$ content in soil was almost twofold higher $(99 \mathrm{mg} / \mathrm{L})$. The similar situation was found for Mn concentration in orchid leaves from the Sloka site, which was similar to that at Silzemnieli, L. Kan- 


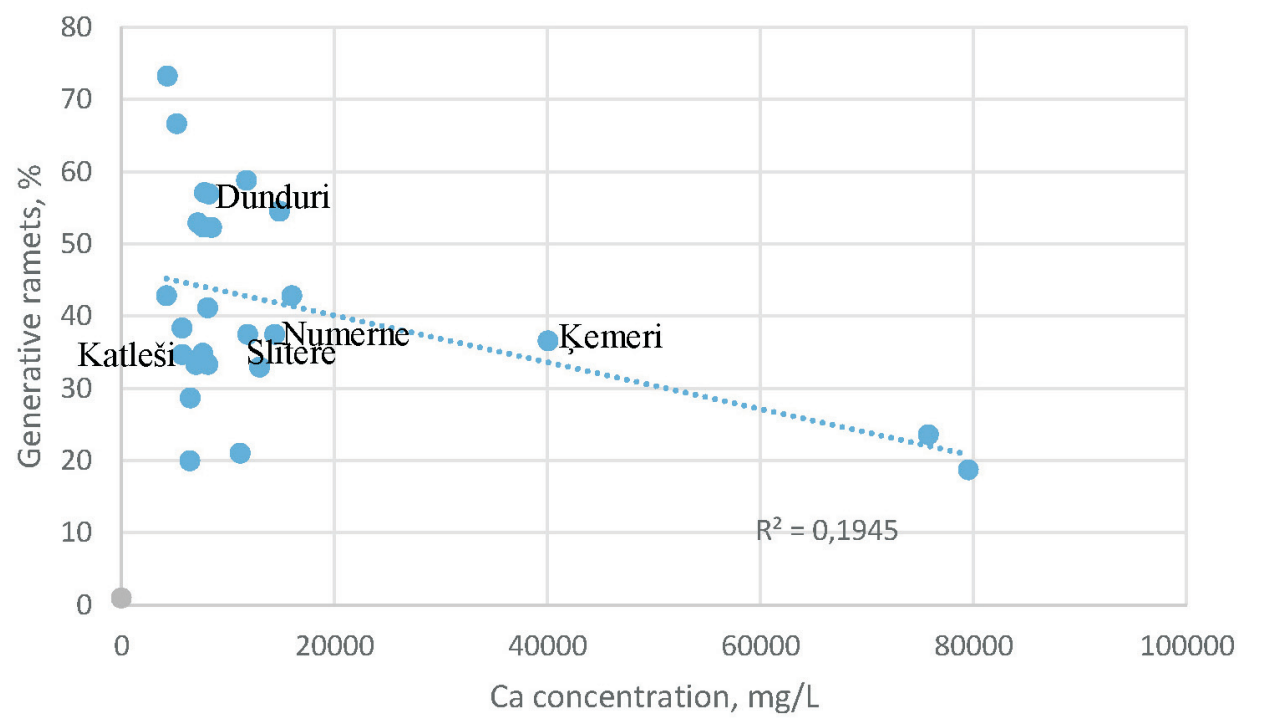

Fig. 4. Correlation between $\mathrm{Ca}$ concentration in soils and abundance of generative ramets of $C$. calceolus (the largest populations of Cypripedium calceolus: Kemeri 1400 ramets, Katleši - 1135 ramets, Dunduri - 511 ramets, Numerne - 304 ramets, Slītere - 200 ramets).
Table 3

CONCENTRATION OF NUTRIENTS IN AIR-DRY CYPRIPEDIUM CALCEOLUS LEAVES FROM DIFFERENT SITES

\begin{tabular}{l|c|c|c|c|c|c|c}
\hline Elements & Kemeri & Sloka & $\begin{array}{c}\text { Silzem- } \\
\text { nieki }\end{array}$ & $\begin{array}{c}\text { L. } \\
\text { Kangari }\end{array}$ & Egḷpe & Katleši & Max/ Min \\
\hline \multicolumn{7}{l}{ Macronutrients, \% } \\
$\mathrm{N}$ & 2.20 & 2.27 & 2.28 & 1.75 & 1.80 & 1.93 & 1.30 \\
$\mathrm{P}$ & 0.26 & 0.24 & 0.24 & 0.20 & 0.14 & 0.34 & 2.43 \\
$\mathrm{~K}$ & 2.12 & 2.07 & 1.86 & 0.82 & 1.94 & 2.09 & 2.58 \\
$\mathrm{Ca}$ & 0.81 & 1.18 & 1.22 & 1.71 & 1.59 & 0.83 & 2.11 \\
$\mathrm{Mg}$ & 0.33 & 0.24 & 0.29 & 0.41 & 0.28 & 0.22 & 1.86 \\
$\mathrm{~S}$ & 0.10 & 0.22 & 0.13 & 0.12 & 0.09 & 0.10 & 2.44 \\
$\mathrm{Micronutrients,} \mathrm{mg} / \mathrm{kg}$ & & & & & \\
$\mathrm{Fe}$ & 109 & 88 & 78 & 160 & 125 & 160 & 2.05 \\
$\mathrm{Mn}$ & 31 & 48 & 45 & 46 & 46 & 74 & 2.41 \\
$\mathrm{Zn}$ & 43 & 35 & 42 & 30 & 24 & 45 & 1.89 \\
$\mathrm{Cu}$ & 6.4 & 6.1 & 3.9 & 5.0 & 3.8 & 15 & 4.00 \\
$\mathrm{Mo}$ & 0.23 & 0.23 & 0.22 & 0.25 & 0.25 & 0.30 & 1.36 \\
$\mathrm{~B}$ & 15 & 21 & 30 & 18 & 16 & 17 & 2.00 \\
& & & & & &
\end{tabular}

gari, and Eglupe, while soil Mn concentration $22 \mathrm{mg} / \mathrm{L}$, mentioned in Sloka, was tenfold lower than in the other sites.

\section{DISCUSSION}

C. calceolus has been reported to grow in moderately moist, nutrient-poor to moderately nutrient-rich, particularly nitrogen-poor, alkaline-neutral to moderately acid soils with pH 5.4-7.9 (Kull, 1999; 2003). However, Arditti (1992) reported that $C$. calceolus is a north temperate terrestrial species that naturally grows in soils that are low in macronutrient content and with high soil reaction ( $\mathrm{pH} 7.1-7.4)$. Therefore, soil conditions are likely not strongly limiting for this species.

In Latvia $C$. calceolus localities are very fragmented. They are found in various forest types - Myrtilloso-polytrichosa,
Myrtilloso-sphagnosa, Dripterioso-caricosa, Caricosophragmitosa, and Oxalidosa turf. mel. Myrtilloso-turf. mel. with significantly heterogeneous soils on parent soil containing carbonate (Liepa, 2005). The sites Slapjo salu purvs, Druviena, Lielie Kangari, Kazu grava, and Kemeri have soils developed on dolomite bedrock with $\mathrm{Ca}: \mathrm{Mg}$ from 1.5 to 4.0, while Pērlupe, Gravinas, Dunduri, Klāṇi are on limestone bedrock with Ca:Mg of 50-125 (Fig. 2). This is also highly consistent with the geological data for Latvia (Juškevičs et al., 1999). The results of soil analysis showed that $\mathrm{Ca}$ and $\mathrm{Mg}$ concentrations are sufficient for successful plant growth (with the exception of $\mathrm{Mg}$ in the Dunduri site), regardless of soil $\mathrm{pH}$. The concentrations of $\mathrm{Ca}$ and $\mathrm{Mg}$ in soils correspond to adequate or high levels for crops (Rinkis and Ramane 1989) and flower cultures (Nollendorfs (1983). The Ca and partly $\mathrm{Mg}$ concentrations in C. calceolus leaves were found to be sufficient and conformed to reference values for epiphytic orchids (Jones et al., 1991) and for bulbous flowers (Nollendorfs, 1983).

For plant nutrition the most optimal $\mathrm{Ca}: \mathrm{Mg}$ ratio in soils using $1 \mathrm{M} \mathrm{HCl}$ extraction is 5-8:1 (Rinkis and Nollendorf, 1982). There were nine sites (Slītere, Murmastiene, Stikli, Silzemnieki, Ziemeḷu purvi, Īsliena, Zāgadi, Katleši, Svēte) with favourable $\mathrm{Ca}: \mathrm{Mg}$ ratio between 6 and 10 for nutrient uptake from the soil.

Soil $\mathrm{pH}$ can play an important role in the distribution of terrestrial orchids by affecting germination, growth of seedlings and plants (Arditti, 1992). Soils rich in calcium and with limestone parent soil (Gravinas, Pērlupe) are more able to neutralise acid deposition than sand or gravel. Carbonates are more alkaline and produce a higher $\mathrm{pH}$ when dissolved in water and can buffer acidity of the rain water or metabolic processes acidifying soil. For $C$. calceolus in Latvia, soil $\mathrm{pH}$ is not a major factor affecting population size and vitality. The two largest populations, in Kemeri and Katleši, were found on soils with different soil reaction: $\mathrm{pH}_{\mathrm{KCl}} 5.65$ and 7.09, accordingly. The three next largest populations, at Dunduri, Slitere, and Numerne, occur on soils with $\mathrm{pH}_{\mathrm{KCl}}$ 6.0-6.4. Soil chemical analyses from 
C. calceolus localities in Estonia also showed a similar range for soil pH (5.4-7.5) (Kull 1999; 2003), while in central Europe and Ukraine the $\mathrm{pH}$ in $C$. calceolus habitats is higher than 7.0 (Kull, 1999; Reshetjuk, 2011).

Plant growth requires sufficient macronutrient level in soil. The proportion of organic matter in soils can also affect mineral nutrient uptake by plants. Although soils where $C$. calceolus grows in Latvia were not rich in nitrogen, the concentrations were sufficient when compared to those reported for European terrestrial orchid habitats (Arditti, 1992, Kull, 1999). Significantly higher concentration of $N$ was found for $C$. calceolus in Ukraine (Reshetjuk, 2011). As C. calceolus sites in Latvia occur mainly on organic soils or mineral soils with high content of organic matter, additional supply with nitrogen during summer might arise from mineralisation of organic matter and nitrification. The $\mathrm{N}$ concentrations in orchid leaves varied around $2.00 \%$ and corresponded with a low to sufficient level reported for orchids (Jones et al., 1991; Arditti, 1992). It is well established that nitrogen concentration in leaves has positive correlation with photosynthesis capacity (Zhang et al., 2006) and some Cypripedium species have a greater photosynthesis adaptation ability than narrowly specific species (Zhang et al., 2006a).

Since $C$. calceolus has relatively low requirements for nutrients (Kull, 1999), in some cases high P content in soil (Svēte, Tūja, Lielie Kangari, Silzemnieki) possibly depressed seed germination. There were no or only a few seedlings observed in these sites. A similar phenomenon was observed for terrestrial orchids in the USA (Sheviak, 1983). On the other hand, C. calceolus is adapted to very heterogenic environment conditions and as a mycotrophic plant can receive $\mathrm{P}$ and other nutrients from symbiotic relationships in poor soils (Dearnaley, 2007). The great majority of mycorrhizal fungi associated with the Cypripedium genus are members of narrow clades within the fungal family Tulasnellaceae (Shefferson et al., 2005). It is possible that rare occurrence of the fungus or its specific environmental demands may affect occurrence of orchid species (McCormick and Jacquemyn, 2014). Phosphorous concentration in orchid leaves was sufficient in all of the sites studied, with values from 0.20 to 0.24 , except at Eglupe, where the soil $\mathrm{P}$ concentration was also low. It is interesting that a low $\mathrm{P}$ concentration in soil was also found in the Kemeri site, where leaf $\mathrm{P}$ concentration was significantly higher, indicating impact of other factors than nutrient level in soils on nutrient uptake in plants.

Similar as for nitrogen, the concentrations of $\mathrm{K}$ in soils of C. calceolus habitats in Latvia were comparable with those in Estonia and Germany, but were significantly lower than in Ukraine (Kull, 1999; Reshetjuk, 2011). K concentration in C. calceolus leaves in Latvia varied between $1.86 \%$ and $2.12 \%$ which indicates the minimal sufficiency requirements (2.10-3.5\%) for epiphytic orchids (Jones 1991). A serious $\mathrm{K}$ deficiency was found in L. Kangari with a $\mathrm{K}$ level in leaves of only $0.82 \%$. This site occurs on mineral soil with low organic matter and $\mathrm{K}$ content, while $\mathrm{Mg}$ concen- tration was very high. The most favourable $\mathrm{Mg}$ and $\mathrm{K}$ ratio in soil (1 $\mathrm{M} \mathrm{HCl}$ extract) for optimal plant mineral nutrition is $2: 1$ (Rinkis and Nollendorf, 1982). Thus, high levels of $\mathrm{Mg}$ might retard $\mathrm{K}$ uptake from soil.

There is almost no information on required $\mathrm{S}$ concentration in soils for terrestrial orchids. Our study showed high heterogeneity in soil S levels; $\mathrm{S}$ concentration in $C$. calceolus leaves was below $0.15 \%$ in most samples, which is considered low (Nollendorfs, 1983; Jones Jr. et al., 1991).

In general, a wide concentration range of mobile forms of micronutrients $\mathrm{Fe}, \mathrm{Mn}, \mathrm{Zn}, \mathrm{Cu}, \mathrm{Mo}$, and $\mathrm{B}$ in $1 \mathrm{M} \mathrm{HCl}$ soil extract were found in C. calceolus sites in Latvia, due to different types of soils, forests, as well as other biotic factors.

A neutral and alkaline soil reaction is considered to be one of the main factors causing deficiency of micronutrients in plants (Marshner, 1995). In some sites (Graviņas, Pērḷupe) there is potential risk of Fe deficiency due to high soil reaction and very low Fe concentration in soil. A non-optimal Fe:Mn ratio was also found for these sites. While optimal Fe : Mn ratio in soils using $1 \mathrm{M} \mathrm{HCl}$ extraction is more than 10:1 (Rinkis and Nollendorf, 1982), in C. calceolus habitats on slope forests a ratio $\mathrm{Fe}: \mathrm{Mn}<1$ was observed. Considering the reported leaf sufficiency levels (Nollendorfs, 1983; Jones Jr et al., 1991; Arditti, 1992), the Fe, Mn, and Zn concentrations in $C$. calceolus leaves analysed were sufficient for successful orchid growth.

Significant deficiency of $\mathrm{Cu}$ and $\mathrm{B}$ was found in C. calceolus leaves for at least half of the samples analysed. In general, the results of soil analyses also revealed low levels of $\mathrm{Cu}$ (less than $2.0 \mathrm{mg} / \mathrm{L}$ ) in soils with $C$. calceolus. In addition, $\mathrm{Cu}$ is readily and tightly complexed by organic matter (Rinkis and Ramane, 1989; Marshner, 1995), suggesting reduced $\mathrm{Cu}$ availability due to the high level of organic matter found in majority of soils from $C$. calceolus sites.

Very high B sufficiency levels were reported for epiphytic orchid leaves: from $40 \mathrm{mg} / \mathrm{kg}$ to $200 \mathrm{mg} / \mathrm{kg}$ (Jones et al., 1991; Arditti, 1992). Boron levels found in our study varied between 15 and $30 \mathrm{mg} / \mathrm{kg}$ and only in the Silzemnieki site corresponded to optimal levels for flower cultures (Nollendorfs, 1983; Mills and Jones, 1996). In contrast, almost optimal soil B concentrations in $1 \mathrm{M} \mathrm{HCl}$ extraction (1.0-2.0 $\mathrm{mg} / \mathrm{L}$ ) for bulbous flowers and main crop plants (Nollendorfs, 1983; Rinkis et al., 1989) were found for C. calceolus soils in Latvia. The availability of $\mathrm{B}$ to plants is affected by a variety of factors, including soil $\mathrm{pH}$ and $\mathrm{Ca}$ : $\mathrm{B}$ ratio. A high $\mathrm{Ca}$ concentration in soil, independent of soil $\mathrm{pH}$, can reduce B uptake (Marshner, 1995; Fageria, 2009).

There are very limited recommendations for optimal Mo levels in soils and leaves for temperate terrestrial orchids. Although high soil reaction can promote Mo accumulation in plants, the results of our study showed that Mo concentration in C. calceolus leaves did not reach $0.5 \mathrm{mg} / \mathrm{kg}$, the 
lower recommended leaf tissue concentration for various plants (Nollendorfs, 1983; Riņkis and Ramane, 1989).

A negative correlation $(\mathrm{r}=-0.44 ; p 0.05)$ was observed between relative number of generative ramets of $C$. calceolus and $\mathrm{Ca}$ concentration in the soil (Fig. 4) and weak positive correlation $(\mathrm{r}=0.21)$ between total number of ramets of $C$. calceolus in a site and $\mathrm{Ca}$ concentration in the soil. Thus, in habitats with more calcareous soils (higher Ca concentrations in the soil), C. calceolus tended to produce more ramets but relative abundance of generative ramets of $C$. calceolus tended to be lower. It should be stressed that there was no linear correlation between percentage of generative ramets and $\mathrm{Ca}$ concentration at the soil, the $\mathrm{Ca}$ concentration range of $4245-16000 \mathrm{mg} / \mathrm{L}$ is typical for most of the C. calceolus habitats in Latvia, indicating $\mathrm{Ca}$ sufficiency and/or species adaptation to wide-ranging Ca supply. However, the highest proportions of generative ramets (50-70 $\%$ ) were found in C. calceolus sites with the Ca concentration in soil in the range 4300-8500 $\mathrm{mg} / \mathrm{L}$.

Overall the obtained results from 27 sites showed high heterogeneity in soil chemical composition for Cypripedium calceolus in Latvia. Although the concentrations of nutrients were comparable with levels obtained in Estonia and Germany (Kull, 1999), the range of variation for $\mathrm{Ca}, \mathrm{Mg}$, Mn was higher. The results showed a weak relationship between soil organic matter concentration and size of orchid population. It was found that soil $\mathrm{pH}$ and $\mathrm{Ca}$ concentration are not the major factors affecting the size and vitality of C. calceolus populations in Latvia.

There was no significant correlation between nutrient concentration in soils and $C$. calceolus leaves, suggesting strong impact of other soil-related factors determining the availability of nutrients. In general, the levels of $\mathrm{N}, \mathrm{P}, \mathrm{K}$, $\mathrm{Ca}, \mathrm{Mg}, \mathrm{Fe}, \mathrm{Mn}$, and $\mathrm{Zn}$ concentrations in C. calceolus leaves were sufficient or slightly decreased for successful orchid growth. The study showed deficiency of S, Cu and B in the vast majority of leaf samples.

The determined diverse soil conditions in C. calceolus habitats helps to understand species growth and sustainability conditions in relation with various plant communities in different forest types.

\section{AKNOWLEDGMENTS}

The present work is developed in the framework of the projects of Fund of Environmental Protection of Latvia during 2010-2015. No. 1-08/46/2010; 1-08/38/2011; 1-08/43/2012; 1-08/157/2013;1-08/423/2014. The study was financially supported by the National Research Programme 2014-2017 „EVIDEnT” (Agreement No. 10-4/VPP-2/19).

\section{REFERENCES}

Ābele, G., Birkmane, K., Vimba, E., Kḷaviņa, G., Rasiņš, A., Riekstiņš, I., Tabaka, L., Fatere, I., Jukna, J. (1978). Chorology of the Latvian flora [Хорология флоры Латвийской ССР. Редкие видь растений I группь охраныл]. Zinātne, Riga. 80 pp. (in Russian).
Andrušaitis, G. (Ed.) (2003). Red Data Book of Latvia. Institute of Biology of University of Latvia, Riga. $691 \mathrm{pp}$.

Anonymous (2000). Analytical Methods for Atomic Absorbtion Spectrometry. PerkinElmer Instruments LLC. Available at:

http://www1.lasalle.edu/ prushan/Intrumental\%20Analysis_files/AA-Per kin\%20Elmer\%20guide\%20to\%20all!.pdf (accessed 2 February 2017).

Anonymous (2012). Nature data system OZOLS. Nature Conservation Agency. Available at:

www.daba,gov.lv/public/lat/dati1/dabas_datu_parvaldibas_sistema_ozols/ (accessed 12 February 2017).

Arditti, J. (1992). Fundamentals of Orchid Biology. John Wiley \& Sons, New York. 691 pp.

Auniņš, A. (ed.) (2013). Eiropas Savienības aizsargājamie biotopi Latvijā [European Union Protected Habitats in Latvia]. Ministry of Environmental Protection and Regional Development of the Republic of Latvia, Riga. 359 pp. (in Latvian).

Cepurīte, B. (2005). Latvijas vaskulāro augu flora. 7: Orhideju dzimta [Vascular Flora of Latvia. 7: Orchid family]. University of Latvia, Riga. 71 pp. (in Latvian).

Cribb, P. (1997). The genus Cypripedium. Timber Press, Portland, 301 pp.

Dearnaley J. (2007). Further advances in orchid mycorrhizal research. Mycorrhiza, 17 (6), 475-486.

Devillers-Treschuren, J. (1999). Action plan for Cypripedium calceolus Europe (Nature and Environment, No. 100). Council of Europe Publishing, Strasbourg, $58 \mathrm{pp}$.

Fageria, N. K. (2009). The Use of Nutrients in Crop Plants. CRC Press, Boca Raton. 430 pp.

Fowler, J., Cohen, L., Jarvis, P. (1998). Practical Statistics for Field Biology. $2^{\text {nd }}$ edn. Wiley, Chichester. 259 pp.

Jones, Jr, J. B., Wolf, B., Mills, H. A. (1991). Plant Analysis Handbook. Micro-Macro Publishing, Athens. 213 pp.

Juškevičs, V., Mūrnieks, A., Misāns J. (1999). Latvijas ǵeoloǵiskā karte [Geological Map of Latvia]. Ministry of Environmental Protection and Regional Development State Geological Survey, Riga. 52 pp.

Kḷavina, D, Grauda, D., Priede, A., Rashal, I. (2014). The habitat diversity and genetic variability of Cypripedium calceolus in Latvia. In: Papers of the $6^{\text {th }}$ Planta Europa Conference on the Conservation of Plants 23-27 May 2011. Krakow, pp. 91-97.

Kull, T. (1999). Cypripedium calceolus L. J. Ecol., 87, 913-924.

Kull, T. (2003). Cypripedium calceolus L. Interpreting population trends through short-term and long-term monitoring. In: Monitoring of Threatened Vascular Plants in Estonia and Finland - Methods and Experiences (The Finnish Environment, 659). Helsinki, pp. 71-78.

Laiviņš, M., Krampis, I. (2004). Jauna augu un dzīvnieku kartēšanas sistēma Latvijā [A new system of plant and animal mapping in Latvia]. In: $A b$ stracts of 62th scientific conference of University of Latvia: Geography, geology, environmental science. Riga, pp. 82-83 (in Latvian).

Liepa, I. (2003). Meža enciklopēdija [Forest Encyclopaedia]. Zelta grauds, Riga, pp. 197-198 (in Latvian).

Marschner, H. (1995). Mineral Nutrition of Higher Plants. Academic Press, London. 889 pp.

McCormick, M. K., Jacquemyn, H. (2014). What constrains the distribution of orchid populations? New Phytologist, 202 (2), 392-400.

Mihalchuk (2011). Structure and dynamics of Cypripedium calceolus populations in natural and technogenically dangerous landscapes of Belaruss Polesye. In: Ohrana i kultivirovanie orhideii. Materiali IX Meždunarodnoi naučnoi konferencii (Sankt-Peterburg, 26-30 September, 2011), Moskva, pp. 305-310. [Охрана и культивирование орхидеи. Материаль IX международной научной конференции.] (in Russian)

Mills, H. A., Jones Jr., J. B. (1996). Plant Analysis Handbook II. MicroMacro Publ. Athens, Georgia. 422 pp. 
Page, A. L., Miller, R. H., Keeney, D. R. (eds.) (1982). Methods of Soil Analysis. Part 2. Chemical and Microbiological Properties. Wisconsin. 1159 pp.

Nollendorfs, V. (1983). Sīpolpuķu mēslošana [Fertilisation of bulbous flovers]. Avots, Riga. 168 pp. (in Latvian).

Reshetjuk, O. V. (2011). Structural analysis of Cypripedium calceolus populations in Ukraine. In: Ohrana $i$ kultivirovanie orhideii. Materiali IX Meždunarodnoi naučnoi konferencii (Sankt-Peterburg, 26-30 September, 2011), Moskva, pp. 348-352. [Охрана и культивирование орхидеи. Материаль IX международной научной конференции.] (in Russian)

Rinkis, G. J., Nollendorf, V. F. (1982). Macro and Micronutrients in Balanced Nutrition of Plants [Ринькис, Г. Я., Ноллендорф, В. Ф. Сбалансированное питание растений макро- и микроэлементами]. Zinatne, Riga. 202 pp. (in Russian).

Riņkis, G., Ramane, H. (1989). Kā barojas augi [Plant Nutrition]. Avots, Rīga. 151 pp. (in Latvian).

Rinkis, G., Ramane, H., Kunicka, T. (1987). Methods of Soil and Plant Analysis [Ринькис, Г. Я., Рамане, Х. К., Куницкая, Т. А. Методы анализа почв и растений]. Zinatne, Riga, 174 pp. (in Russian).
Riņkis G., Ramane H., Paegle G., Kuṇicka T. 1989. Optimisation System and Diagnostic Methods of Plant Mineral Nutrition [Ринькис, Г. Я., Рамане, Х. К., Паэгле, Г. В, Куницкая, Т. А. Система оптимизации и методы диагностики минерального питания растений]. Zinatne, Riga. 196 p. (in Russian)

Shefferson, R. P., Weis, M., Kull, T., Taylor, D. L. (2005). High specificity generally characterizes mycorrhizal association in rare lady s slipper orchids, genus Cypripedium. Molecular Ecology, 14, 613-626.

Sheviak, C. J. (1983). United States terrestrial orchids: Patterns and problems. In: North American Terrestrial Orchids: Symposium II Proceedings and Lectures. Plaxton, E. H. (Ed.). Michigan Orchid Society, Michigan, MI, pp. 49-60.

Zhang, S.-B., Hu, H., Xu, K., Li, Z.-R. (2006). Gas exchanges of three co-occurring species of Cypripedium in a schrubland in the Hengduan Mountains. Photosynthetica, 44 (2), 241-247.

Zhang S.-B., Hu, H., Xu, K., Li Z.-R. (2006a). Photosynthetic performances of five Cypripedium species after transplanting. Photosynthetica, 44 (3), $425-432$.

\section{AUGŠN̦U K̦ĪMISKAIS RAKSTUROJUMS CYPRIPEDIUM CALCEOLUS AUGTENĒM LATVIJĀ}

Ilgākā laika periodā (2007-2015) pētītas Eiropas direktīvu aizsargātas sugas dzeltenās dzegužkurpītes Cypripedium calceolus visas 27 Latvijas atradnes. Lai noskaidrotu C. calceolus izplatības limitējošos faktorus, sākām ar augteņu augšņu analīzi. Konstatēta augsta augšņu kīmiskā sastāva heterogenitāte ar īpaši plašu Ca, Mg, Mn variāciju. C. calceolus Latvijas atradnes atrodas galvenokārt uz organiskām augsnēm vai uz augsnēm ar augstu organiskās vielas saturu. Iegūtie rezultāti uzrāda saistību starp organiskās vielas saturu un šis orhidejas populācijas lielumu. Turpretī konstatêts, ka augsnes pH nav izšķirošais faktors, kas nosaka rametu skaitu augtenē. Tā kā netika konstatēta cieša saistība starp minerālelementu saturu auga lapās un augsnē, var secināt, ka barības vielu uzṇemšanā liela nozīme ir ne tikai elementu koncentrācijai, bet arī citiem ar augsni saistītiem faktoriem. Kopumā N, P, K, Ca, Mg, Fe, Mn un Zn saturs C. calceolus lapās vērtējams kā augšanai adekvāts vai nedaudz pazemināts. Vairumā lapu paraugu tika identificēts S, Cu un B deficīts. Konstatēta vāja pozitīva korelācija ( $\mathrm{r}=0.21)$ starp C. calceolus kopējo rametu skaitu augtenē un Ca koncentrāciju augsnē, kas arī liecina, ka augsnes īpašības nav galvenais faktors, kas nosaka sugas augšanas sekmes katrā konkrētā augtenē. 